The Varieties of Resource Experience:

How Natural Resource Export Structures

Affect the Political Economy of Economic G rowth

by

Jonathan Isham, Michael Woolcock, Lant Pritchett and G wen Busby

April 2003

MIDDLEBURY COLLEGE ECONOMICS DISCUSSION PAPER NO. 03-08

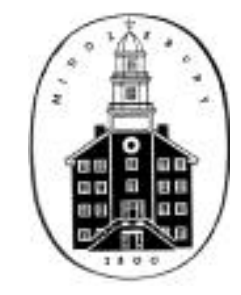

DEPARTMENT OF ECONOMICS

MIDDLEBURY COLLEGE

MIDDLEBURY, VERMO NT 05753

http:/ / www.middlebury.edu/ econ 


\title{
The Varieties of Resource Experience: How Natural Resource Export Structures Affect the Political Economy of Economic Growth ${ }^{*}$
}

\author{
Jonathan Isham \\ Middlebury College \\ Lant Pritchett \\ Harvard University
}

\author{
Michael Woolcock \\ World Bank and Harvard University \\ Gwen Busby \\ Cornell University
}

This draft: April 30, 2003

\begin{abstract}
Many oil, mineral, and plantation crop-based economies experienced a substantial deceleration of growth since the commodity boom and bust of the 1970s and early 1980s. Rodrik (1999) has demonstrated that the magnitude of a country's growth deceleration since the 1970s is a function of both the magnitude of the shocks and a country's "social capability" for adapting to shocks. In this paper, we demonstrate that in this respect countries, with what we term "point source" natural resource exports are doubly disadvantaged. Not only are countries with these types of exports exposed to terms of trade shocks, but the institutional capability for responding to shocks is itself endogenous and negatively related to export composition. Using two different sources of export data and classifications of export composition, we show that point source and coffee/cocoa exporting countries do worse across an array of governance indicators (controlling for a wide array of other potential determinants of governance). This is not just a function of being a "natural resource" exporter, as countries with natural resource exports that are "diffuse" do not show the same strong differences—and have had more robust growth recoveries.
\end{abstract}

Keywords: economic growth, institutions, natural resource endowment

JEL Codes: 013; 050; Z13

\footnotetext{
* We thank William Easterly, Dani Kaufmann, Michael Ross, and Michael Schott for their rapid and informative sharing of data and ideas, and Richard Auty, Jean-Philippe Stijns, Phani Wunnava, and participants at seminars at UNU/WIDER, Middlebury College, the World Bank, and the University of Cambridge for useful comments. We also thank Maya Tudor for research assistance, and the Department of Economics and the Program in Environmental Studies at Middlebury College for research support. An earlier version of this paper (Woolcock, Pritchett and Isham 2001) was prepared for (and sponsored by) the UNU/WIDER Project on Resource Abundance and Economic Growth. Please address comments to jisham@ middlebury.edu, mwoolcock@worldbank.org, and lant pritchett@harvard.edu
} 
The rentier state is a state of parasitic, decaying capitalism, and this circumstance cannot fail to influence all the socio-political conditions of the countries concerned.

\section{Vladimir Lenin, Imperialism, the Highest Stage of Capitalism ${ }^{1}$}

It matters whether a state relies on taxes from extractive industries, agricultural production, foreign aid, remittances, or international borrowing because these different sources of revenues, whatever their relative economic merits or social import, have powerful (and quite different) impact on the state's institutional development and its abilities to employ personnel, subsidize social and economic programs, create new organizations, and direct the activities of private interests. Simply stated, the revenues a state collects, how it collects them, and the uses to which it puts them define its nature.

Terry Karl, The Paradox of Plenty ${ }^{2}$

[I]t is useful to contrast the conduct of governments in resource-rich nations with that of governments in nations less favorably endowed. In both, governments search for revenues; but they do so in different ways. Those in resource-rich economies tend to secure revenues by extracting them; those in resource-poor nations, by promoting the creation of wealth. Differences in natural endowments thus appear to the shape the behavior of governments.

Robert Bates, Prosperity and Violence: The Political Economy of Development ${ }^{3}$

\section{Introduction}

Is oil wealth a blessing or curse? Norway provides a hopeful example, but Azerbaijanis are rightly concerned whether their country can handle the potential bonanza from newly discovered oil fields. While government officials have promised that oil revenues will go to schools, hospitals and roads, no formal plans are in the offing; meanwhile, neighboring Caspian Sea nations are despotically ruled, ethnically divided, and weakened by corruption—problems some fear will be made worse by oil ${ }^{4}$. The controversy over the construction of the pipeline in Chad

${ }^{1}$ Cited in Ross (2001: 329, fn. 6)

${ }^{2} \operatorname{Karl}(1997: 13)$

${ }^{3}$ Bates (2001: 107, fn. 1)

${ }^{4}$ According to the chief UN representative in Azerbaijan, "This wealth ... will create a lot of problems. It will increase the already substantial gap between the rich and poor, and eventually it will affect political stability" (Kinzer 1999). 
demonstrates that even in an extraordinarily poor country, not all believe that additional wealth pouring into government coffers will lead to better times.

Both resource scarcity and abundance have been cited as a primary cause of civil war. Some have argued that land scarcity is behind the Rwandan conflicts (e.g., Klare, 2001), but resource-rich countries have not escaped civil strife. Angola had been embroiled in conflict since the mid 1970s, and the "problem" there is not scarce land, but rather abundant sources of oil and some of the world's best diamonds (Campbell, 2002). Just as revenues from diamonds, timber, coffee and gold in the eastern half strengthened (then) Zaire's elite, revenues from Col tan are now strengthening the rebel Rally for Congolese Democracy ${ }^{5}$. Rebels in Sierra Leone are financed from diamond mines, and are perhaps fighting over nothing else except for control over them.

What mechanisms might explain the conditions under which resource abundance becomes a problem rather than part of a solution to development? We add to the burgeoning literature on natural resources and performance by documenting one way in which countries' sources of export revenue affect economic growth ${ }^{6}$. We show that export concentration in what we term "point-source" natural resources—-those extracted from a narrow geographic or economic base such as oil, minerals (e.g. copper, diamonds), and plantation crops (e.g. bananas)_-is strongly associated with weak public institutions which are, in turn, strongly associated with slower growth. This paper presents econometric evidence to support the hypothesis that not only is institutional capacity to handle shocks a determinant of economic

\footnotetext{
${ }^{5}$ Columbine-tantalite (Col-tan) has recently been declared 'the wonder mineral of the moment': when processed, it is vital for the manufacture of capacitors and other high tech products.

${ }^{6}$ The most recent literature on the effects of natural resources on growth includes Auty 1995; 2001; Leamer et al 1999; Leite and Weidmann 1999; Ross 1999, 2001; Sachs and Warner 1995 [2000], 1999; Stijns 2001; Nugent and Robinson 2001; Gylfason and Zoega 2002, Lederman and Maloney 2002.
} 
growth since the "commodity shocks" of the 1970s and 1980s (Rodrik 1999), but that institutional capacity itself varies across economies with different sources of export revenue, and that it is these export structures that influences socioeconomic and political institutions.

Figures 1 and 2 (from Woolcock, Pritchett and Isham 2001) illustrate the growth performance facts we are trying to (partially) explain. Figure 1 shows the smoothed (over three years) median developing country annual growth rate of GDP per capita. From the mid 1950s until the late 1970s this was consistently above 2 percent. But since 1980 the developing economies have endured a growth collapse of "Grand Canyon" proportions, with growth near zero for much of the period. Figure 2 is even more striking, as it shows that the growth performance of ninety developing economies classified by their export structure in 1985 (we turn to the exact definitions of the categories below). Countries that were exporters of manufacturers have not experienced a growth deceleration at all. All natural resource exporters suffered substantial slow-downs, but the deceleration was much more severe and lasted much longer for "point source" and "coffee/cocoa" exporters than for countries whose principal exports were what we term "diffuse." Why? 


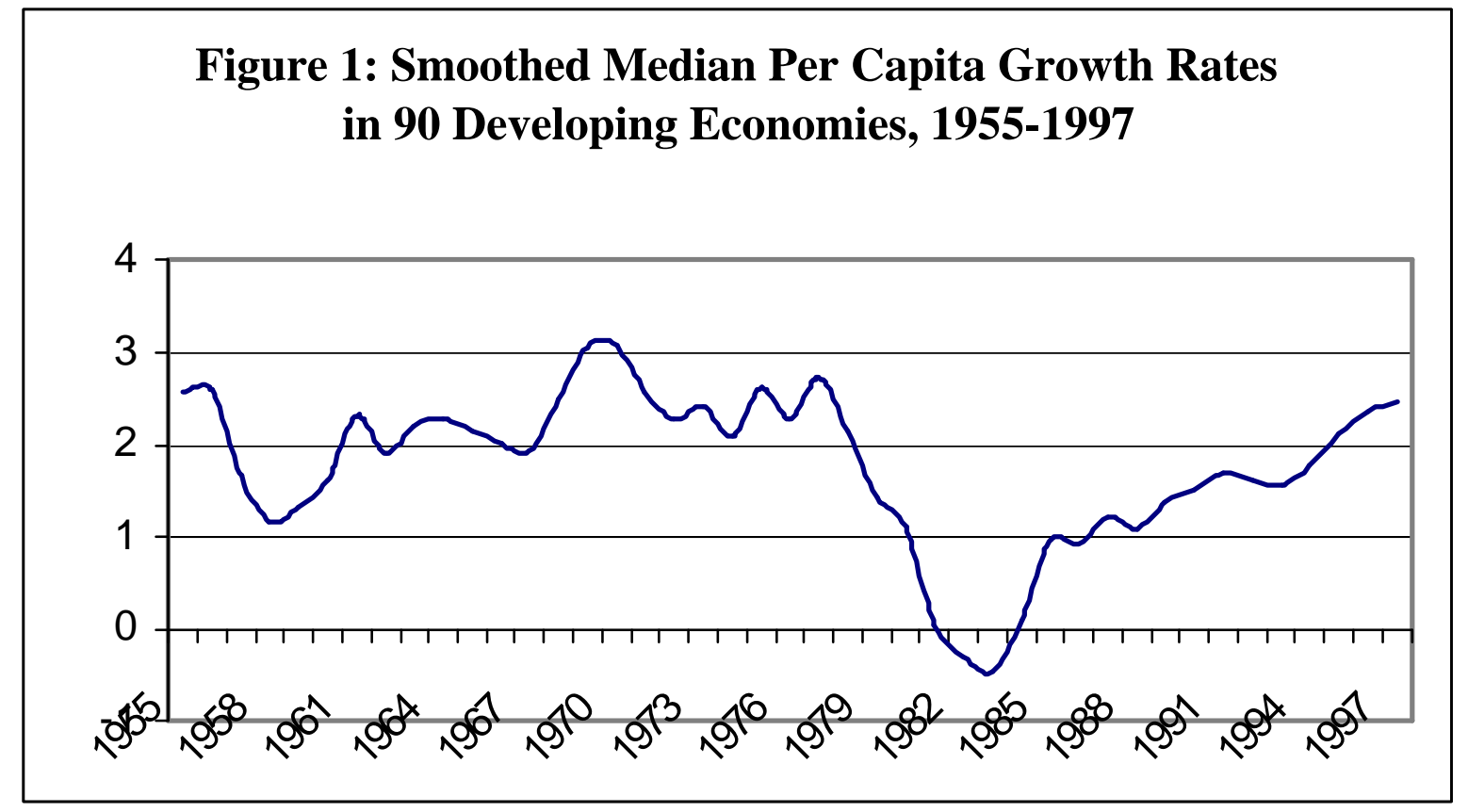

Figure 2: Smoothed Median Growth Rates for 90 Developing Economies, 1957-1997

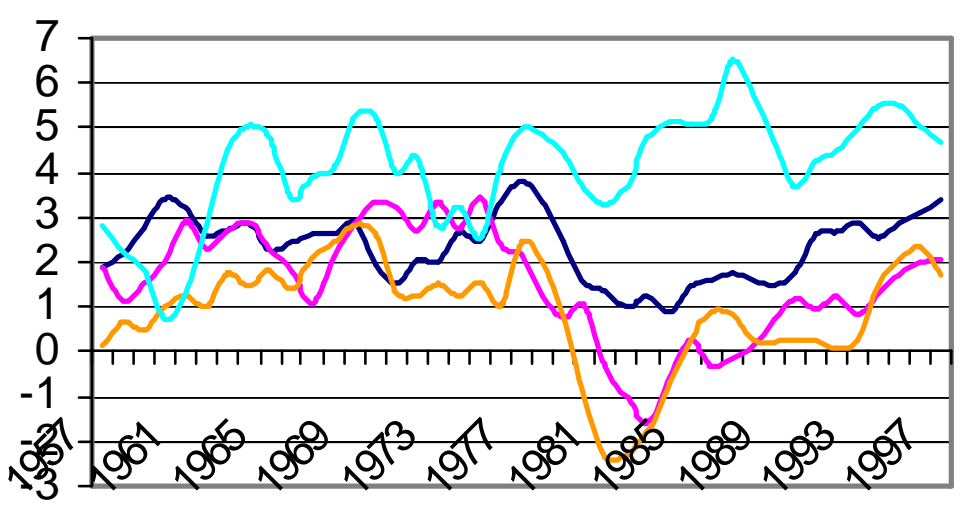

\begin{tabular}{|c|}
\hline Diffuse $(\mathrm{N}=18)$ \\
Point Source \\
$(\mathrm{N}=45)$ \\
Coffee/Cocoa \\
$(\mathrm{N}=18)$ \\
Manufacturing \\
$(\mathrm{N}=9)$ \\
\hline
\end{tabular}


We focus on the variety of resource experience and show that export composition-both between natural resources and manufactures but also amongst different types of natural resources_-influences the quality of political institutions. Section II discusses the literature on natural resources and growth, in particular the range of hypotheses that are consistent with a link between resource composition and governance. Section III discusses our two measures of export structure. Section IV shows the link between these and indicators of governance, and then completes the circle by showing the link between indicators of governance and economic growth since. Section V concludes, with some speculations for "policy."

\section{II: Development of our hypothesis}

Ross's (2001) excellent empirical investigation into the mechanisms by which oil undermines democracy outlines several possible channels or "effects" through which oil affects political outcomes. We draw on his analysis to discuss three such mechanisms: rentier effect, delayed modernization effect, and an entrenched inequality effect. All of these are consistent with a negative link between particular types of resources and government capacity.

Rentier States. Political scientists generally—and area specialists in particular_argue that certain natural resources undermine development through what they term "rentier effects" $\left(\right.$ Ross 2001) ${ }^{7}$. When revenues can be easily extracted from a few sources that are easily

7 Some historians of the early modern state (e.g., Chirot, 1998) argue that the increasing cost of modern armies led to greater demands on the state's ability to raise revenues, which led to one of several outcomes. States with access to exogenous resources (e.g. the Spanish crown) did not have to extract resources from the domestic population and so did not develop any of the forms of the mo dern state. In other cases, either (a) an accommodation was reached between the sovereign and other classes about their permission/assistance in taxation (classic case: England), (b) an increasingly powerful sovereign extracted resources directly (classic case: France), or (c) an 
controlled there are three consequences. First, for any given revenue target, the state has less need for taxation of the population, and without the pressure for taxation the state has less need to develop mechanisms of deep control of the citizenry. By the same token, citizens have less incentive to create mechanisms of accountability and develop the deep "civil society" and horizontal social associations that many feel are the "preconditions" of democracy (Lipset (1959), Moore (1966), Putnam (1993), and Inglehart (1997)). Second, with the "exogenous" revenues, the government can mollify dissent through a variety of mechanisms (buying off critics, providing the population with benefits, infrastructure projects, patronage or outright graft). Third, the state has resources to pursue direct repression and violence against dissenters. Delayed Modernization. For influential scholars such as Barrington Moore (1966), the story of wealth, power, and political and economic transformation begins with some smallish group of elites owning the most valuable resources (usually land); from this land they extract a surplus from the peasants in some way or another (serfdom, slavery, feudal exactions), but then economic circumstances change so that industrialization is necessary. Modernization requires that (a) some of the surpluses be transferred from existing activities to new industrial activities, (b) at least some of the labor be moved to the new activities, and (c) a more sophisticated system be put in place to manage the political pressures generated by urbanization and the demands of new semi-professional urban dwellers and business groups ${ }^{8}$. This combination of economic transformations sets off a series of shifts in political power that can lead in various directions depending on how the coalitions of landed elite/rural producer/urban labor/new industrialists/urban "middle class" plays out. This process can go more or less rapidly and can

inability to mobilize revenues because of conflicts between sovereign and nobles meant that eventually one got gobbled (classic cases: Poland, Hungary).

${ }^{8}$ Acemoglu and Robinson (1999) model precisely these trade-off by the elites. 
lead to representative democracy, fascism, corporatism, Marxist dictatorships, or oligarchies (Moore 1966). Recently, Acemoglu, Johnson, and Robinson (2001) have used similar arguments in which the mortality of settlers plays a crucial role in determining the structure of economic production and hence institutions. In high mortality environments, settlers concentrated only on rent extraction from high value added products and hence did not "invest" in developing high quality government institutions.

Moreover, states who control a "point source" resource would resist industrialization because it means creating several alternative sources of power (urban labor, urban middle class, urban industrialists) each of whom, as their power grows, will want to tax away (or just confiscate) the quasi-rents from the natural resources. In the cross section of levels, this implies that countries that are still today dominated by "point source" products are also likely to be dominated by elite politics of one type or another. In this case we do want to bring the OECD countries in, because they are countries that successfully made the transition from agricultural production to industrialization (and beyond) and in the process created functioning democratic polities (although via very different paths — the US/UK path to democracy is very different from the French, Prussian/German, or Japanese one). Indeed, viewed over the span of the last hundred years, it is only quite recently that resource-poor countries have become systematically wealthier than resource-rich countries (see Auty 2001: 5).

Political scientists have long argued that states dependent on natural resources tend to thwart secular modernization pressures-e.g. higher levels of urbanization, education, and occupational specialization—because their budget revenues are derived from a small work force 
that deploys sophisticated technical skills that can only be acquired abroad (e.g., oil is largely extracted by foreign, not domestic, firms). As a result, neither economic imperatives nor workers themselves generate pressures for increased literacy, labor organizations, and political influence. Concomitantly, citizens are therefore less able to effectively and peacefully voice their collective interests, preferences, and grievances (even in nominally democratic countries such as Zimbabwe and Jamaica). In short, resource abundance simultaneously "strengthens states" and "weakens societies", and thus yields—or at least perpetuates_low levels of development (cf. Migdal 1988). ${ }^{9}$

Entrenched Inequality. The "entrenched inequality" effect is that the export composition affects economic and political outcomes by affecting the social structure. Economic historians Engerman and Sokoloff $(1997,2000)$ argue that the diverging growth trajectories of South and North America over the last two hundred years can be explained by reference to the types of crops grown, the extent of property rights regimes enacted to secure their sale, and the timing and nature of colonization. In North America, crops such as wheat and corn were grown on small family farms, cultivatable land was relatively abundant, but de-colonization occurred early and innovative property rights ensured that land (and assets more generally) could be sold on an open market. In South America, by contrast, crops such as sugar, coffee, and cocoa were grown on large plantations, cultivatable land was relatively scarce, de-colonization occurred late, and property rights were weak. Landed elites were able to amass great personal fortunes, resist more

\footnotetext{
${ }^{9}$ There are many variants on the way in which resources delay modernization, which center on different connections between states and elites. The state can own the rents and a regime of rentier autocrats emerges, as with Algeria and Nigeria; or, rentier capitalists can effectively own the state, as in Angola and El Salvador, and oligarchic regimes emerge.
} 
democratic reforms, and consolidated power. ${ }^{10}$ During downswings, vested interests thus resist reforms that would diversify the economy, because this would create "rivals" competing for labor and government influence. ${ }^{11}$ Certain types of natural resources are thus predisposed to generating an influence on the long-run level of development: ergo, North America's resource base enabled it to became rich, but South America's did not. ${ }^{12}$

The social dimension of "entrenched inequality" is that some areas of geographic space are conducive to small-holder production on individually owned plots. The interactions among these producers tend to be horizontal relationships of equality. In other areas of geographic space, production is conducive to large-scale production (e.g. plantations of bananas). In these regions the relationships tend to bind each person to a social superior (noble, land-owner), and the horizontal relationships among producers tend to be ones of distrust. This economic structure then produces a social structure that is conducive to "bad" politics (clientelism) and to "bad" governance ( since citizens cannot cooperate to demand better services from the state).

Implications of all three stories. We do not propose that the empirical results below are the "test" of some particular model; rather they are consistent with a variety of possible models. First, all involve some connection from the structure of economic production, and in particular exports, to some measure of the capacity and quality of government. Second, it is not

${ }^{10}$ From this perspective, the warmer southern states in North America, with their plantation crops (tobacco) and enduring commitment to slavery, were a microcosm of the larger contrast between North and South America. ${ }^{11}$ See Tornell and Lane (1999) for a model of how special interests can dampen economic growth. On the institutional side, their argument is very much in the spirit of this paper: they als o note (echoing Barro 1996) that one possible explanation for the distributive struggle in many countries is the attempt to appropriate rents generated by natural resource endowments.

${ }^{12}$ Consider the contrast between Argentina and United States. Carlos Diaz-Alejandro conjectured the entire difference in political and economic evolution between Argentina and the United States can be explained by the fact that in Argentina land gets better from west (last settled) to east (first settled), while in the USA land gets better from east (first settled) to west (last settled). Hence in Argentina, population growth led to larger and larger rents on the good land that was divvied up early while in the USA the western expansion rapidly undermined the position of the landed elites. In Argentina the families who controlled the large parts of the pampas were also classic nineteenth 
just exports of "natural resources" that matter, but the production characteristics. The actual geographic pattern of production matters, particularly as it affects the ease with which the state can control and extract the "rents." In particular, while others have focused (rightly) on dimensions of natural resource exports such as lack of diversification ${ }^{13}$ and exposure to secular terms of trade decline (and volatility), we stress the effect of exports on politics and only then indirectly on economic performance. Third, while many of our stories for growth involve very long run effects, there is also a connection with changes in growth rates through the combination of weak institutions and shocks.

\section{Creating a measure of export structure}

Our hypothesis can therefore be stated as follows. Different types of natural resource endowments matter for economic growth by generating a differential capacity to respond to economic (and other) shocks. In particular, countries dependent on point-source natural resources and plantation crops are predisposed to heightened social divisions and weakened institutional capacity, which in turn impede their ability to respond effectively to shocks. The effective and equitable management of shocks—and economic transitions more generally—is a key to sustaining rising levels of prosperity.

In this paper we take the link between endowments and export structure as given—that countries with oil are more likely to export oil and that countries can only export crops like coffee and cocoa if they have appropriate climates. This link has a reasonable base in theory and

century liberals - advocates of free trade, property rights, limited government, no industrial policy (except for processing of raw materials like refrigeration for beef).

${ }_{13}$ Note that our classification of "diffuse" is about the conditions of production of any given commodity, not "diversification" across different commodities. 
evidence. Our measures of the "quality" of government are typically from the 1980s and 90s. We use export structure from prior to that period so that, at least with respect to post-1980 growth and currently assessed institutional quality, export structure is pre-determined. The weak link in determining the chain of causation is that it is possible that historical factors affect institutions and this in turn determines whether a country will develop a manufacturing capability and export manufactures, and hence the link between poor governance and exports is caused by poor governance. However, this argument is much less compelling against the arguments about the differences of types of natural resource exports.

\section{A) Data on export composition}

To test this hypothesis we create classifications of export structures according to their natural resource base using two methods.

First, we use UNCTAD's Handbook of International Trade and Development Statistics (1988) for data on the leading exports of every country in 1985 that had a GNP per capita under $\$ 10,000$ and a population greater than one million. We classified countries based on their top two SITC three digit exports into four types:

- 'Manufacturing exporters', who relied on exports of manufactures (without regard to labor or capital intensity).

- 'Diffuse' economies, which have relied primarily on animals and agricultural produce grown on small family farms (e.g., rice and wheat).

- 'Point source' economies, which have relied primarily on fuels, minerals, and plantation 
crops (e.g. sugar);

- 'Coffee and cocoa' economies, which have relied primarily on these two commodities (classifying them as either 'point source' or 'diffuse' proved problematic since these crops can be grown either on plantations or small family farms, but since these tree crops rely on a long time scale and are immobile, they are potentially susceptible to rent extraction from small holders via marketing boards.)

We relied on jud gments from country and commodity experts when there was some ambiguity about a country's classification. The countries used in this analysis, with their classifications, are presented in Appendix Table 1, which also lists the description of the first and second most important export categories with their share in total exports.

The second method was to compute four indices of 'net export shares' that mirror our four classifications of the types of exports: (1) manufacturing; (2) diffuse, (3) point source, and (4) coffee and cocoa. To construct these four indices, the World Trade Analyzer from 1980 was used to aggregate SITC codes at the two-digit level into our four export categories, following the approach of Leamer et al. (1999). To calculate the 'ne t export share' for each sub-category, net exports (X-M) of sub-category $i$ is divided by the sum of the absolute value of net exports across all sub-categories (following the procedure in Leamer et al.,1999). The four indices are then calculated as the sum of the net export shares for each sub-category in each of the four categories. By construction, these indices have a range of -1 to 1 , with a higher number indicating a greater relative reliance on the corresponding category for export earnings. Reassuringly, the two methods give similar results, as shown in Table 1. The 
'manufactures index' is -.02 for the manufactures exporters compared to $-.38,-0.35$, and -0.43

for the resource exporters. The diffuse, point source, and coffee and cocoa indices are highest

for each of the corresponding set of UNCTAD-based classifications (in the rows), so that moving diagonally in the lower right of the table, $0.08,0.28$, and 0.16 , respectively are higher than other row entries ${ }^{14}$.

\section{Table 1: Export compositions and the natural resource base of selected developing economies}

\begin{tabular}{|c|c|c|c|c|}
\hline Data source & \multicolumn{4}{|c|}{$\begin{array}{c}\text { Statistics Canada World Trade Data Base } \\
\text { (1980) }\end{array}$} \\
\hline $\begin{array}{l}\text { UNCTAD- } \\
\text { based } \\
\text { Classification: }\end{array}$ & $\begin{array}{l}\text { Manufactures } \\
\text { index }\end{array}$ & Diffuse index & $\begin{array}{l}\text { Point source } \\
\text { index }\end{array}$ & Coffee and Cocoa index \\
\hline All countries & -0.34 & 0.03 & 0.11 & 0.06 \\
\hline \multicolumn{5}{|l|}{ of which: } \\
\hline $\begin{array}{l}\text { Manufacturing } \\
\text { exporters }\end{array}$ & -0.02 & -0.05 & -0.12 & 0.01 \\
\hline Diffuse & -0.38 & 0.08 & -0.04 & 0.04 \\
\hline Point source & -0.35 & 0.01 & 0.28 & 0.04 \\
\hline $\begin{array}{l}\text { Coffee and } \\
\text { cocoa }\end{array}$ & -0.43 & 0.06 & -0.02 & 0.16 \\
\hline
\end{tabular}

Notes: means of selected export and trade related data for 90 developing economies. See text for descriptions of country classifications, data and data sources.

\section{B) Differences in growth and institutional quality across export categories}

We now begin to develop our argument that the nature of export composition—measured by these four indices_-affects economic growth via political and social institutions. First, Table 2 shows the growth story that we introduced with Figures 1 and 2. Since 1974, growth rates have been massively different between developing countries that export manufactures and resourceexporter countries—almost 4 percentage points per annum different (4.58 versus 0.65$)$. The difference is due in large part to the different in the deceleration of growth. Whereas the growth

\footnotetext{
14 The classification of countries also produces reasonable results when compared with standard sources like the World Development Indicators (WDI) (1999). Over the 15 year period before the oil shock manufactures were only 10.6 percent of exports for resource exporters versus 46.8 percent for merchandise exporters.
} 
in the exporters of manufactures increased by one percentage point, that of the resource exporters decelerated by almost two percentage points (1.89) for a three percentage point differential (these magnitudes of growth rate differences maintained over time have enormous implications - if two countries begin with equal income today the country growth three percentage points faster would be more than twice as rich in only 22 years). More importantly for our hypothesis about the importance of the composition of natural resource exports, growth rates are also significantly different (using the Mann-Whitney test) between the types of resource exporters. Diffuse economies have done almost as well as their pre-oil shock performance (decelerating by “only” 0.43), while point source have decelerated by 2.57 percentage points and coffee/cocoa economies have decelerated by 1.65 percentage points.

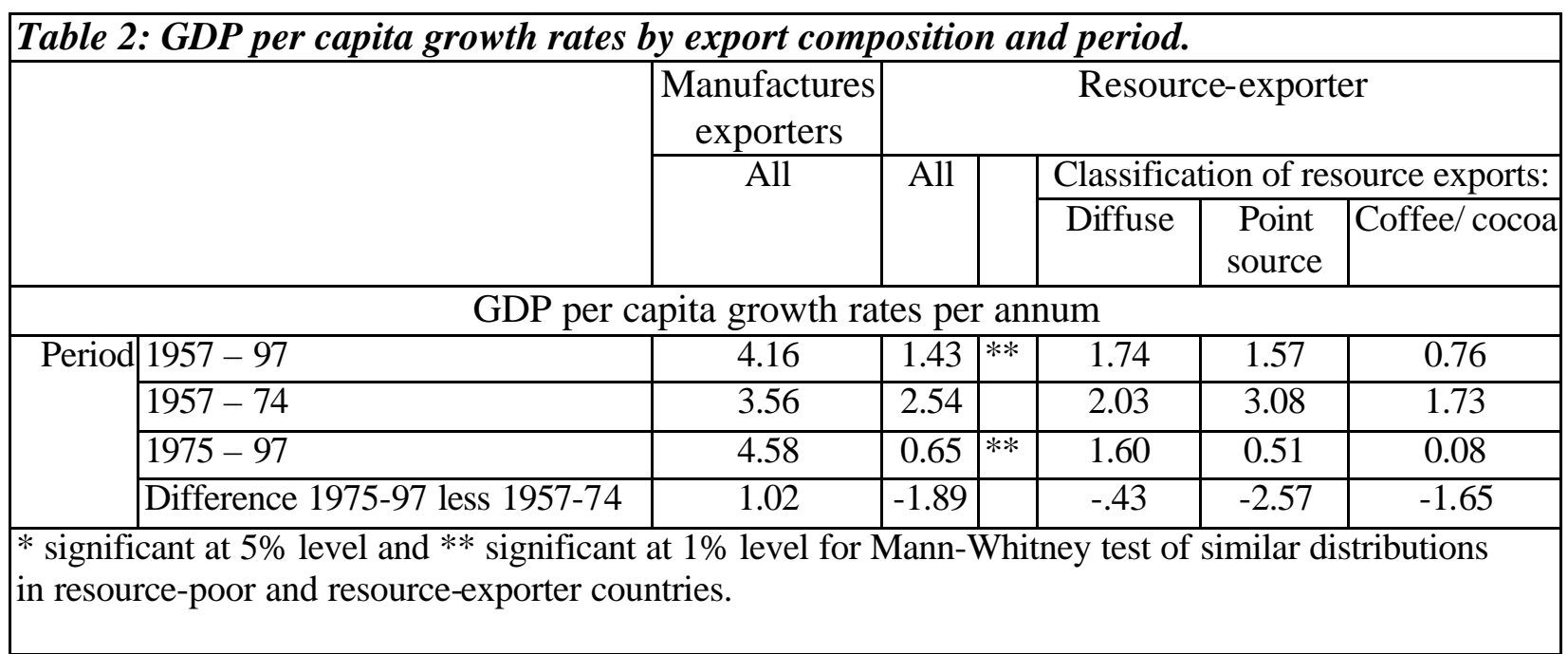

Second, in Table 3, we also compare the averages across these exporter classifications for eleven institutional variables, which have been used as indicators of "institutional quality" in the empirical growth literature ${ }^{15}$. There is no question that the manufactures exporters appear to

15 These "institutional" variables that have been used recently in a set of papers on the institutional determinants of economic growth (Knack and Keefer 1995; Rodrik 1999a, Kaufmann et al. 2000; Dollar 2000, Ritzen, Easterly and Woolcock 2000, and Easterly 2001). Growth rate data for the period 1957-1997 was compiled 
have higher institutional quality — the indicator is lower among the resource-exporter countries in all cases and for six of these this difference is statistically significant ${ }^{16}$. However, the differences among the types of resource exporters are not impressive: while diffuse exporters tend to have better institutional quality, the differences are small and not statistically significant.

\begin{tabular}{|c|c|c|c|c|c|c|c|}
\hline \multicolumn{3}{|c|}{ Table 3: Institutional quality and export composition } & amon & $g n$ & nety deve & ping & omies. \\
\hline & & \multirow{3}{*}{$\begin{array}{l}\text { Exporters of } \\
\text { manufactures }\end{array}$} & \multicolumn{5}{|c|}{ Resource-exporter } \\
\hline & & & \multirow{2}{*}{$\begin{array}{l}\text { All } \\
\text { RE }\end{array}$} & & \multicolumn{3}{|c|}{ Type of resource exports: } \\
\hline & & & & & Diffuse & $\begin{array}{c}\text { Point } \\
\text { source }\end{array}$ & $\begin{array}{l}\text { Coffee/ } \\
\text { cocoa }\end{array}$ \\
\hline \multicolumn{2}{|c|}{ Number of countries: } & 9 & 81 & & 18 & 45 & 18 \\
\hline Source & Variable & & & & & & \\
\hline Kaufmann & Rule of law & 0.33 & -0.45 & $* *$ & -0.40 & -0.40 & -0.66 \\
\hline \multirow[t]{5}{*}{$\begin{array}{l}\text { Kraay, } \\
\text { Zoboda }\end{array}$} & $\begin{array}{l}\text { Political instability and } \\
\text { violence }\end{array}$ & 0.28 & -0.38 & $*$ & -0.27 & -0.40 & -0.43 \\
\hline & Government effectiveness & 0.32 & -0.41 & * & -0.45 & -0.35 & -0.51 \\
\hline & Control of corruption & 0.23 & -0.41 & $*$ & -0.37 & -0.36 & -0.57 \\
\hline & Voice and accountability & 0.04 & -0.34 & & -0.24 & -0.36 & -0.39 \\
\hline & Regulatory burden & 0.40 & -0.17 & & -0.14 & -0.19 & -0.11 \\
\hline \multirow[t]{2}{*}{ ICRG } & Law and Order Tradition & 3.81 & 2.85 & $*$ & 2.80 & 2.89 & 2.81 \\
\hline & Quality of the Bureaucracy & 3.71 & 2.59 & $* *$ & 2.52 & 2.63 & 2.55 \\
\hline \multirow{2}{*}{$\begin{array}{l}\text { Freedom } \\
\text { House }\end{array}$} & Political rights & 3.98 & 3.28 & & 3.50 & 3.26 & 3.12 \\
\hline & Civil Liberties & 3.56 & 3.35 & & 3.49 & 3.33 & 3.24 \\
\hline CPIA & $\begin{array}{l}\text { Property rights and rule- } \\
\text { based governance }\end{array}$ & 3.60 & 3.37 & & 3.53 & 3.28 & 3.42 \\
\hline \multicolumn{8}{|c|}{$\begin{array}{l}\text { Notes: The sources for these institutional variables are Kaufmann et al. (2000) (for KKZ), Easterly } \\
\text { (2000) (for ICRG and Freedom House) and World Bank (2002) (for CPIA). } \\
\text { * significant at } 5 \% \text { level and ** significant at } 1 \% \text { level for Mann-Whitney test of similar distributions } \\
\text { in resource-poor and resource-exporter countries. }\end{array}$} \\
\hline
\end{tabular}

from the Penn World Tables and the World Development Indicators (World Bank 1999). Measures of social and political data were adapted from Kaufmann et al. (2002) ${ }^{15}$, Easterly (2000), and World Bank (2002).

${ }^{16}$ From the KKZ data, 'rule of law', 'political instability', 'government effectiveness', and 'control of corruption'; from ICRG, 'law and order tradition' and 'quality of the bureaucracy.' 


\section{Regressions: government quality and exports}

Using our continuous indices of export composition, we can move beyond the simple cross-tabs in two ways. We use regressions that measure the intensity of the export concentration within type, and the regressions control for the composition of all four types for each country. We estimate a two equation system. In the first, institutional variables are endogenously determined by export composition as well as the other correlates of institutional quality that have been proposed in the literature-e.g., a country's share of English and European language speakers, latitude, and 'predicted trade share' (Hall and Jones (1999), Kaufmann, Kraay, Zoboda (2000) and ethnic fractionalization (as used in Ritzen, Easterly, and Woolcock 2000, Alesina, et al. 2002). Growth is then determined by institutions (and the other usual suspects from the growth regression literature).

We estimate an equation for each of six indicators of institutional quality measured in the 1990s ('rule of law', 'political instability and violence', 'government effectiveness', 'control of corruption', 'regulatory framework', and 'property rights and rule-based governance') as a linear function of the four indices of net export composition measured in 1980, plus five other (relatively) predetermined variables: 'English language', 'European language', 'distance from equator', 'predicted trade share', 'ethnolinguistic fractionalization', all of the usual growth determinants (X's listed below), and a set of regional dummies.

Growth over the period 1975 to 1997 is estimated as a linear function of an indicator of institutional quality (included one at a time), lagged GDP per capita, lagged secondary school 
achievement, the Sachs-Warner indicator of trade openness, changes in the terms of trade, and the share of primary exports to GDP, and a set of regional dummies.

(1) $I_{i, 1990 s}^{j}=\beta_{0}+\sum_{k=1}^{4} \beta_{N R}^{k} * N R_{i}^{k}+\sum_{l=1}^{5} \beta_{W}^{l} * W_{i}^{l}+\sum_{m=1}^{5} \beta_{X}^{m} * X_{i}^{m}+\operatorname{Re}$ gion Dummies $+\varepsilon_{i}^{j}, j=1, . .6$

(2) Growth $\mathrm{i}_{\mathrm{i}} \mathrm{a}_{0}+\mathrm{a}_{1} * \mathrm{I}_{\mathrm{ij}}+\mathrm{a}_{2} * \mathrm{X}_{\mathrm{i}}+$ ? $_{\mathrm{i}}$

In particular, we call attention to two of the growth determinants. First, we include in the growth regression the terms of trade, to be sure that we are not simply capturing the effect of falling terms of trade. Second, we also include the share of primary exports to GDP, which was done in a pair of influential papers by Sachs and Warner (1995 [2000], 1999), who argue that having abundant natural resources makes you less competitive in manufacturing exports, and manufacturing exports have some happy features like learning spillovers that make them "extra good" for growth. Originally we thought that the channel through institutions might be a better "explanation" of the presence of the "primary share" in a growth regression. However, including the regional variables in a sample of developing countries already makes the pure "primary exports" variable statistically insignificant. Even so, we include the share of exports that are "primary" as a growth regressor, because this means we can be sure the impacts of export structure are due to the composition among types of primary exports, not simply that any natural resource has the same impact.

First, we present the results for estimating equation (1), based on a three-staged least squares (3SLS) estimation of this system of equations. ${ }^{17}$ These results establish whether

${ }^{17} 3$ SLS estimates are more efficient than IV estimates if the error terms below are correlated and the sytem is not exactly identified. 
measures of the natural resource endowment — using the four indices derived from Statistics Canada—predict the nature of socioeconomic and political institutions. Table 4 illustrates the results of equation (1) for the six chosen institutional variables. ${ }^{18}$ As shown in the first two rows, neither the 'manufactures index' nor the 'diffuse index' are statistically significant predictors of any of the six institutional variables.

${ }^{18}$ From 62 to 66 of the 90 countries that are used to derive Tables 1 and 2 have the required data to estimate these models. The countries included in these estimations are noted with an asterisk in the second column of Appendix Table 1. 


\section{Table 4: The effect of the natural resource endowment on institutions}

(1)

Rule of law
(2)

Political Government instability effectiveness
(4)

Control of corruption
(5)

Regulatory

framework
Manufactures index

Diffuse index

Point source index

Coffee and cocoa index

Ethnic fractionalization

Predicted trade share

Latitude

English language

European language

GDP per capita

Secondary school achievement

Trade openness

Change in terms of trade

Share of primary exports/GDP

Sub-Saharan Africa

Europe and Middle East

Latin America

East Asia

Adjusted r-squared
Sample size$$
-0.02
$$$$
\text { (0.23) }
$$$$
-0.08
$$$$
\text { (0.34) }
$$$$
-1.48 * *
$$$$
\text { (0.26) }
$$$$
-2.05 * *
$$$$
(0.69)
$$$$
0.0027
$$$$
\text { (0.0023) }
$$$$
0.06
$$$$
\text { (0.10) }
$$$$
-0.0058
$$$$
\text { (0.0044) }
$$$$
0.10
$$$$
\text { (0.29) }
$$$$
0.92 * *
$$$$
\text { (0.32) }
$$

$0.127 * *$

(0.046)

$0.024 *$

(0.010)

$$
0.55 * *
$$$$
(0.20)
$$$$
-0.01
$$$$
\text { (0.18) }
$$

$$
1.27 *
$$$$
\text { (0.53) }
$$

0.18

$$
\text { (0.28) }
$$

$$
0.87 \text { ** }
$$$$
\text { (0.29) }
$$$$
-0.49
$$$$
\text { (0.33) }
$$$$
0.16
$$$$
\text { (0.29) }
$$

0.71

66
0.05

$(0.29)$

$-0.27$

(0.45)

$-2.09 * *$

(0.33)

$-3.26 * *$

(0.87)

0.0018

(0.0029)

0.06

(0.13)

$-0.0005$

(0.0057)

$-0.44$

(0.36)

$1.18 * *$

(0.40)

$0.195 * *$

(0.059)

0.001

(0.012)

0.31

(0.25)

$-0.09$

(0.23)

$1.46 *$

(0.68)

0.60

(0.36)

$$
0.95 *
$$

(0.37)

0.21

(0.42)

0.43

(0.38)

0.65

65
$-0.48$

(0.26)

$-0.39$

(0.40)

$-1.47 * *$

(0.30)

$-1.64 *$

(0.82)

0.0027

(0.0027)

$-0.09$

$(0.12)$

$-0.0007$

(0.0051)

0.04

(0.33)

$1.11 * *$

(0.37)

$0.150 * *$

(0.053)

$0.029 * *$

(0.011)

0.34

(0.23)

$-0.14$

(0.23)

$1.23 *$

(0.61)

0.44

(0.33)

$0.95 * *$

(0.34)

$-0.37$

(0.38)

0.51

(0.34)

0.63

64
0.02

(0.24)

$-0.21$

(0.36)

-0.95 **

(0.26)

$-1.41 *$

(0.71)

0.0004

(0.0023)

0.12

(0.11)

$-0.0047$

(0.0045)

0.09

(0.29)

0.96 **

(0.32)

0.060

(0.047)

0.034 **

(0.010)

0.17

(0.20)

-0.60 ***

(0.18)

0.15

(0.55)

0.28

(0.29)

0.78 **

(0.30)

$-0.36$

(0.34)

0.08

(0.30)

0.63

64
(6)

Property

rights and

rule-based

governance

$-0.49 \quad-0.27$

(0.30) $\quad(0.24)$

$0.05 \quad-0.29$

(0.45) (0.35)

$-1.09 * * \quad-1.22 * *$

(0.34) (0.27)

$-1.60 \quad-1.07$

(0.89) (0.69)

$0.0022 \quad 0.0059 *$

$(0.0029) \quad(0.0023)$

$0.04-0.13$

(0.13) $\quad(0.11)$

$0.0007 \quad-0.0010$

(0.0056) (0.0042)

$-0.08 \quad-0.25$

(0.37) (0.28)

$0.99 * \quad 1.10 * *$

(0.42) $\quad(0.32)$

$0.058 \quad 0.071$

$(0.061) \quad(0.051)$

$0.029 * \quad 0.034 * *$

(0.013) (0.009)

$0.43 \quad-0.01$

(0.27) (0.19)

$-0.37-0.45 *$

(0.24)

0.89

(0.71)

0.25

(0.37)

0.58

(0.39)

0.03

(0.43)

0.41

(0.40)

0.51

66
(0.20)

$1.77 * *$

(0.52)

0.15

(0.31)

$0.79 *$

(0.33)

$-0.22$

(0.36)

0.23

(0.31)

0.64

62

Notes: test of the effect of natural resouce base indicators on six instiutional variables. See text for descriptions of all variables. * significant at $5 \%$ level; ** significant at $1 \%$ level 
By contrast, as shown in the third row, the 'point source index' is statistically significant in all six specifications: ceteris paribus, an increased dependence on point source natural resources is associated with much worse institutions. From the fourth row, the "coffee and cocoa index' is significant in specifications (1) - (4). ${ }^{19}$ As for the other regressors in this model, 'European language,' 'Secondary school achievement,' and 'Europe and the Middle East' are also statistically significant predictors of these institutional variables. ${ }^{20}$

What are the relative magnitudes of the effects of other significant regressors? Table 5 lists the equivalent of 'beta coefficients' from this 3SLS estimation. ${ }^{21}$ The values for 'point source index' (from -0.38 to -0.71 ) are either the largest (columns 1 and 2) or second largest (columns 3 -6) compared to the values of 'European Language' and the other significant variables. $^{22}$ The values for 'coffee and cocoa index' (from -0.13 to -0.37 ) are generally comparable to those of 'GDP per capita.'

${ }^{19}$ The p-values for specifications (5) and (6) are 0.07 and 0.12 , respectively.

${ }^{20}$ A small note about the scale and definition of 'Per capita GDP (1975)' in this table: it is in US\$1000, adjusted for purchasing power parity.

${ }^{21}$ Figures are calculated as the product of the coefficient and the standard deviation (from the regression sample) of the listed variable, divided by the standard deviation of the dependent variable.

${ }^{22}$ We have excluded the 'Eu rope and Middle East' dummy from this comparison. 


\begin{tabular}{|c|c|c|c|c|c|c|}
\hline \multicolumn{7}{|c|}{ Table 5: The relative magnitude of the effect of the natural resource endowment } \\
\hline & (1) & (2) & (3) & (4) & (5) & (6) \\
\hline & Rule of law & $\begin{array}{l}\text { Political } \\
\text { instability }\end{array}$ & $\begin{array}{l}\text { Government } \\
\text { effectiveness }\end{array}$ & $\begin{array}{l}\text { Control of } \\
\text { corruption }\end{array}$ & $\begin{array}{l}\text { Regulatory } \\
\text { framework }\end{array}$ & $\begin{array}{l}\text { Property rights } \\
\text { and rule-based } \\
\text { governance }\end{array}$ \\
\hline Point source index & -0.58 & -0.71 & -0.57 & -0.41 & -0.38 & -0.46 \\
\hline $\begin{array}{l}\text { Coffee and cocoa } \\
\text { index }\end{array}$ & -0.27 & -0.37 & -0.21 & -0.20 & -0.18 & -0.13 \\
\hline $\begin{array}{l}\text { European } \\
\text { language }\end{array}$ & 0.53 & 0.59 & 0.63 & 0.61 & 0.50 & 0.60 \\
\hline GDP per capita & 0.32 & 0.44 & 0.38 & 0.17 & 0.13 & 0.17 \\
\hline $\begin{array}{l}\text { Secondary school } \\
\text { achievement }\end{array}$ & 0.26 & 0.01 & 0.31 & 0.40 & 0.28 & 0.35 \\
\hline Trade openness & 0.25 & 0.12 & 0.15 & 0.08 & 0.17 & 0.00 \\
\hline $\begin{array}{l}\text { Share of primary } \\
\text { exports/GDP }\end{array}$ & 0.21 & 0.21 & 0.20 & 0.03 & 0.13 & 0.27 \\
\hline Note: figures are th & equivalent of 't & a coefficient & from 3 SLS est & ation & & \\
\hline
\end{tabular}


What are the absolute magnitudes of the effects of the natural resource variables? From specification (1), a country whose 'point source index' fell by a standard deviations ${ }^{23}(=0.266)$ the approximate difference between Angola (0.70) and Cameroon (0.42)—would increase 'rule of law' by 0.39 ; a country whose 'coffee and cocoa index' fell by a standard deviations $(=0.88)$ — the approximate difference between Colombia (0.22) and Ecuador (0.14)—would increase 'rule of law' by 0.37 . Since the standard deviation of 'rule of law' is 0.68 , these represent substantial institutional improvements. To illustrate, the estimated effect of a decrease in one standard deviation of the 'point source index' and of the 'coffee and cocoa index' yields a total change of 'rule of law' by 0.76 , based on the calculations above: this is the equivalent of the difference between Sri Lanka (-0.31) and Thailand (0.44). Given their relative and absolute magnitudes, these overall results are consistent with our first hypothesis: that both point source and coffee and cocoa dependence are critical determinants of socioeconomic institutions.

Next, in Table 6, we present the results of estimating the growth equation to show the strong impact of institutions on post-1974 growth. Five of the six OLS models (specification 1) suggest that institutions are a positive and significant determinant of economic growth among these developing countries from 1975 to 1997 . By contrast, when the four natural resource indices are used as the identifying instruments (specification 2), this generates an estimate that is significant with all six institutional variables — and the point estimate is also greater than the OLS point estimate (which is consistent with the presence of a plausible degree of measurement error in the indicators of institutional quality). When the languages variables and 'latitude' are added to the natural resource instrument set (specification 3), this produces broadly similar results.

\footnotetext{
${ }^{23}$ Here and with the 'beta coefficient' calculations above, we use the standard deviations from the regression sample, as listed in Appendix Table 2.
} 
Table 6: The effect of the institutions on economic growth, 1974-1997

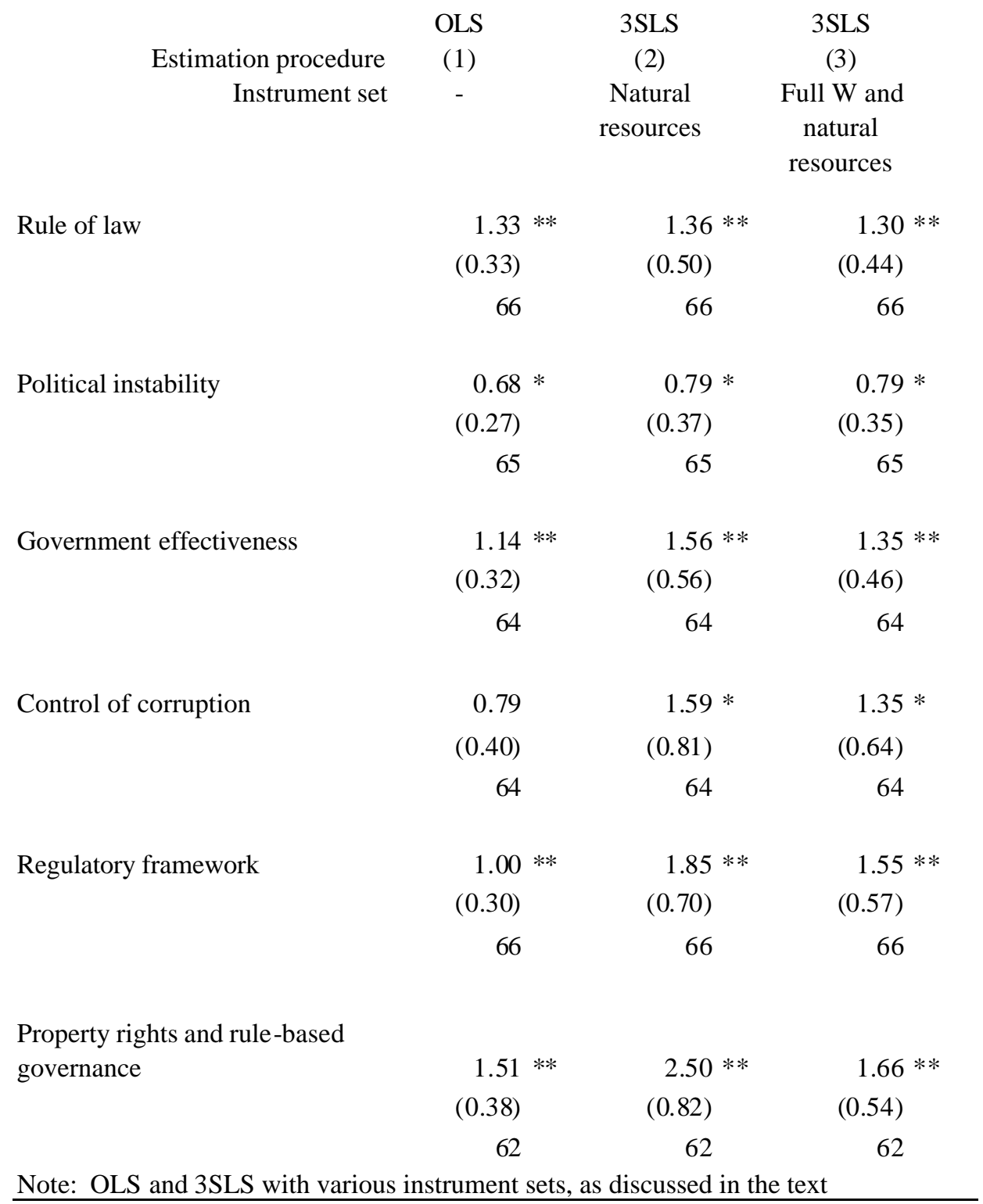

The presence of alternative valid instruments for institutions allows us to test the "exclusion" restriction—that is, that export composition affects growth only insofar as it affects institutions (intuitively, the test is an F-test of the inclusion of the four export composition 
indices in the growth regression with a consistent estimate for the effect of institutions; see Davidson and MacKinnon 1993, Hausman-Taylor 1991). We find no evidence that export composition should be included in the growth regression.

The results in this section comprise the econometric punch line of this paper. First, both point source and coffee and cocoa dependence negatively affect national socioeconomic institutions. Second, institutions that are endogenously determined by the nature of natural resource dependence are significant determinants of growth.

What are the implications of this two-stage effect? In the first part of this section, we noted that a large change in the composition of a country's natural resource endowment-a one standard deviation change in point source and coffee and cocoa dependence-is associated with a relatively large improvement of our measures of socioeconomic institutions. How might such an improvement translate into a change of economic growth? Using the results from Table 4 and specification (3) in Table 6, we calculate the estimated effect of a decrease in one standard deviation of the 'point source index' and of the 'coffee and cocoa index' on economic growth, via better institutions. These calculations yield an annual increase of per capita growth from between 0.51 to 0.75 . Using the median of these figures (0.68), this translates into a GPD per capita that, ceteris paribus, is 19 percent higher, 25 years after the oil shock, among countries with such better institutions than countries with worse institutions. 


\section{V: Discussion and conclusion}

At first glance, ours are stultifying results for the policymaker: like Putnam's (1993) medieval guilds and choral societies, it is hard to imagine how a policymaker interested in accelerating growth can change what we have identified as one possible underlying cause of poor performance—a country's natural resource endowment makes for poor institutions. We admit: it is hard to get beyond this first glance.

But here's why we think it is important to shed light on these results. World Bank (1998) illustrated the power of institutions in development assistance, and what donors should (and most importantly, should not) do in the face of varied institutional performance among potential aid recipients. Our results suggest how entrenched—and 'environmentally determined'—poor institutions can be (cf. Wade (1988), at micro level). So these results, in a certain sense, further raise cautions about casual attempts at institutional reform. Poor institutions are deeply rooted. Where others (e.g., Rodrik 1999) have shown how important institutional quality and social inclusion are to managing growth generally and growth volatility in particular, these results push the chain of causation back further one step further, showing that, pace Karl (1997: 13), "the revenues a state collects, how it collects them, and the uses to which it puts them" does indeed "define its nature". Institutions surely matter a lot, but types of natural resource endowments and the corresponding export structures to which they give rise (rather than "geography"), play a large role in shaping what kinds of institutional forms exist and persist.

There are possibilities for structuring the influences once they are identified, but even this 
is not obvious. In Chad, for instance, outside factors (notably the World Bank) have created 'institutional' conditionality regarding the use of the resources from the oil pipeline that they are helping to finance. (Perhaps this will work, but so far money is still going, defiantly, to the purchasing of arms). In contrast, in Qatar the head of state recognizes that the natural resource gravy train—including the institutions that have gone with it—is leaving the station. He is attempting reform from within and he has decreed (?!) that Qatar will become a democracy: censorship is out, universal suffrage and elections are in.

We are hopeful that in some cases, donors can—if they're lucky—gently nudge along such reforms. At the very least, donors should not maintain (perceived) 'lifeline' aid that prevents the likelihood of nascent reforms from even getting started. Regarding client countries as mere repositories for the steady flow of highly valued—in both the economic and geo-political sense—natural resources such as oil and diamonds, rather than genuine partners in the development process, likely undermines such reform efforts. 


\section{References}

Acemoglu, Daron, Simon Johnson, and James Robinson (2001) 'The colonial origins of comparative development: an empirical investigation' American Economic Review 91(5): 1369-1401

Adelman, Irma and Cynthia Taft Morris (1967) Society, Politics and Economic Development Baltimore: Johns Hopkins University Press

Aron, Janine (1997) 'Political, economic and social institutions: a review of the growth evidence' University of Oxford, Centre for the Study of African Economies: Working Paper Series, 98-4

Auty, Richard (1995) Patterns of Development: Resources, Policy and Economic Growth London: Edward Arnold.

Auty, Richard (2001) 'Introduction and overview', in R.M. Auty (ed.) Resource Abundance and Economic Development New York: Oxford University Press

Baldwin, Robert (1956) 'Patterns of development in newly settled regions' Manchester School of Economic and Social Studies 24: 161-179

Barro, Robert (1997) Determinants of Economic Growth: A Cross-Country Empirical Study Cambridge, MA: MIT Press

Bates, Robert (2000) Prosperity and Violence: The Political Economy of Development New York: Norton

Campbell, Greg (2002) Blood Diamonds: Tracing the Deadly Path of the World's Most Precious Stones Boulder, CO: Westview Press

Collier, Paul (1999a) 'The economic causes of civil war' Oxford Economic Papers and Bulletin

Collier, Paul (1999b) 'The political economy of ethnicity' Annual Bank Conference on Development Economics 1998 Washington, DC: The World Bank

Collier, Paul and Anke Hoeffler (2001) 'Greed and grievance in civil war' Mimeo, The World Bank (Draft: October 21)

Collier, Paul and Jan Willem Gunning (1999) 'Explaining African economic performance' Journal of Economic Literature 37(March): 64-111

Deininger, Klaus (1999) 'A new data set for measuring land inequality' The World Bank, mimeo

Diamond, Jarred (1998) Guns, Germs, and Steel: The Fates of Human Societies New York: Norton

Easterly, William (1999) 'Life during growth” Journal of Economic Growth 4(3): 239-76 
Easterly, William (2001) 'The middle class consensus and economic development' Journal of Economic Growth 6(4): 317-35

Easterly, William (2002) 'Evidence from commodity endowments that inequality does lower per capita income' Mimeo, The World Bank

Easterly, William and Ross Levine (1997) 'Africa's growth tragedy: policies and ethnic divisions' Quarterly Journal of Economics 62(November): 1203-50

Engermann, Stanley and Kenneth Sokoloff (1997) 'Factor endowments, institutions, and differential paths of growth among new world economies: a view from economic historians of the United States," in Stephen Haber, ed. How Latin America Fell Behind, Stanford, CA: Stanford University Press

Evans, Peter (1996) 'Government action, social capital and development: reviewing the evidence on synergy' World Development 24(6): 1119-1132

Filmer, Deon and Lant Pritchett (1999) 'Education comparisons' Population and Development Review 25(1):

Gylfason, Thorvaldur and Gylfi Zoega (2002) 'Inequality and Economic Growth: Do Natural Resources Matter?' Paper presented at the CEFinfo Conference on Growth and Inequality, Munich

Hall, Robert and Charles Jones (1999) 'Why do some countries produce so much more output per worker than others?' Quarterly Journal of Economics 114(1): 83-116.

Hausman, Jerry. 1978. 'Specification Tests in Econometrics,” Econometrica 46: 1251-71.

Hausman, Jerry and W. Taylor. 1981. 'Panel Data and Unobservable Individual Effects," Econometrica 49: 1377 - 98..

Hausmann, Ricardo (forthcoming) 'Venezuela's growth implosion: a neo-classical story?' in Dani Rodrik (ed.) Economic Growth: Analytical Country Narratives Princeton, NJ: Princeton University Press

Inglehart, Ronald (1997) Modernization and Postmodernization: Cultural, Economic, and Political Change in 43 Societies Princeton, NJ: Princeton University Press

Isham, Jonathan, Daniel Kaufmann and Lant Pritchett (1997) 'Civil liberties, democracy, and the performance of government projects,' World Bank Economic Review 11(2): 219-42

Karl, Terry (1997) The Paradox of Plenty: Oil Booms and Petro-States Berkeley, CA: University of California Press.

Kaufmann, Daniel, Art Kray, and Pablo Zoido-Lobatón . (2000). 'Aggregating Governance Indicators' Policy Research Working Paper 2195. Washington: The World Bank.

Kaufmann, Daniel, Art Kray, and Pablo Zoido-Lobatón . (2002). 'Governance Matters II' Policy Research Working Paper 2772. Washington: The World Bank. 
Keefer, Philip and Stephen Knack (1997) 'Why don't poor countries catch up? A cross-country test of an institutional explanation' Economic Inquiry 35(3): 590-602

Kinzer, Stephen. (1999) 'Riches May Roil Caspian Nations' The New York Times January 2, 1999.

Klare, Michael (2001) Resource Wars: The New Landscape of Global Conflict New York: Henry Holt and Company

Knack, Stephen (1999) 'Social capital, growth and poverty: a survey and extensions' College Park, MD: IRIS, University of Maryland (mimeo)

Knack, Stephen and Philip Keefer (1995) 'Institutions and economic performance: cross-country tests using alternative institutional measures' Economics and Politics 7(November): 207227

Knack, Stephen and Philip Keefer (1997) 'Does social capital have an economic payoff? A cross-country investigation' Quarterly Journal of Economics 112: 1251-1288

La Porta, Rafael, Florencio Lopez-de-Silanes, Andrei Shleifer, and Robert Vishney (1997) 'Trust in large organizations' American Economic Review, Papers and Proceedings 87(2): 3338

La Porta, Rafael, Florencio Lopez-de-Silanes, Andrei Shleifer, and Robert Vishney (1998) 'The quality of government' Cambridge, MA: NBER Working Paper \#6727

Leamer, Edward, Hugo Maul, Sergio Rodriguez, and Peter Schott (1999) 'Does natural resource abundance increase Latin American income inequality?' Journal of Development Economics 59: 3-42

Lederman, Daniel and William Maloney (2002) 'Open questions about the link between natural resources and economic growth: Sachs and Warner revisted' Mimeo, The World Bank

Leite, Carlos and Jens Weidmann (1999) 'Does mother nature corrupt? Natural resources, corruption, and economic growth’ IMF Working Paper WP/99/85, Washington, DC

Lipset, Seymour Martin (1959) 'Some social requisites of democracy: economic development and political legitimacy' American Political Science Review 53:

Mahoney, James (2001) The Legacies of Liberalism: Path Dependence and Political Regimes in Central America Baltimore, MD: Johns Hopkins University Press

Mauro, Paolo (1995) 'Corruption and growth' Quarterly Journal of Economics 110(3): 681-712

Migdal, Joel (1988) Strong Societies and Weak States: State-Society Relations and State Capacities in the Third World Princeton, NJ: Princeton University Press

Moore, Barrington (1966) Social Origins of Dictatorship and Democracy Boston: Beacon Press

Olson, Mancur (2000) Power and Prosperity: Outgrowing Communist and Capitalist 
Dictatorships New York: Basic Books

Paige, Jeffrey (1997) Coffee and Power: Revolution and the Rise of Democracy in Central America Cambridge, MA: Harvard University Press

Posner, Daniel (1999) 'Ethnic fractionalization: How (not) to measure it? What does (and doesn't) it explain?' Paper presented at the annual meeting of the American Political Science Association, Atlanta

Pritchett, Lant (2000) 'Understanding patterns of economic growth: searching for hills among plateaus, mountains, and plains' World Bank Economic Review 14(2): 221-50

Putnam, Robert (1993) Making Democracy Work: Civic Traditions in Modern Italy Princeton, NJ: Princeton University Press

Easterly, William, Jo Ritzen and Michael Woolcock (forthcoming) "Social cohesion, institutions, and growth" Economics and Politics

Rodriguez, Francisco and Jeffrey Sachs (1999) 'Why do resource abundant economies grow more slowly? A new explanation and an application to Venezuela' Journal of Economic Growth 4(3): 277-303

Rodrik, Dani (1999a) 'Where did all the growth go? External shocks, social conflict, and growth collapses' Journal of Economic Growth 4(4): 385-412

Rodrik, Dani (1999b) The New Global Economy and Developing Countries: Making Openness Work Baltimore, MD: Johns Hopkins University Press

Ross, Michael (1999) 'The political economy of the resource curse' World Politics 51(1): 297322

Ross, Michael (2001) 'Does oil hinder democracy?' World Politics 53(3): 325-61

Sachs, Jeffrey and Andrew Warner (1995) 'Natural resource abundance and economic growth' Cambridge, MA: NBER Working Paper Series, No. 5398. [Subsequently published in Gerald Meier and James Rauch (eds.) Leading Issues in Economic Development New York: Oxford University Press, 2000]

Sachs, Jeffrey and Andrew Warner (1999) 'The big push, natural resource booms, and growth' Journal of Development Economics 59:

Sokoloff, Kenneth and Stanley Engerman (2000) 'Institutions, factor endowments, and paths of development in the New World' Journal of Economic Perspectives 14(3): 217-32

Stijns, Jean-Philippe (2001) 'Natural resource abundance and economic growth revisited' Mimeo, Department of Economics, University of California at Berkeley

Temple, Jonathan (1998) 'Initial conditions, social capital, and growth in Africa' Journal of African Economies 7(3): 309-347

Temple, Jonathan (2003) 'Growing into trouble: Indonesia after 1966' in Dani Rodrik (ed.) In 
Search of Prosperity: Analytic Narratives on Economic Growth Princeton, NJ: Princeton University Press

Temple, Jonathan and Paul Johnson (1998) 'Social capability and economic growth' Quarterly Journal of Economics 113(3): 965-990

Tendler, Judith (1997) Good Government in the Tropics Baltimore: Johns Hopkins University Press

UNCTAD (1988) Handbook of International Trade and Development Statistics New York: United Nations

Vick (2001)

Wade, Robert (1988) Village Republics: Economic Conditions for Collective Action in South India New York: Cambridge University Press

Weaver (2000)

Woolcock, Michael (1998) 'Social capital and economic development: toward a theoretical synthesis and policy framework' Theory and Society 27(2): 151-208

Woolcock, Michael and Deepa Narayan (2000) 'Social capital: implications for development theory, research, and policy' World Bank Research Observer 15(2): 225-249

Woolcock, Michael, Lant Pritchett and Jonathan Isham (2001) "The social foundations of poor economic growth in resource-rich economies" in R.M. Auty (ed.) Resource Abundance and Economic Development New York: Oxford University Press

World Bank (1998) Assessing Aid: What Works, What Doesn't, and Why New York: Oxford University Press

World Bank (1999) World Development Indicators 99 Washington, DC: The World Bank

World Bank (2002) 'New data on property rights and rule based governance'. Available at http://www1.worldbank.org/publicsector/indicators.ht m (as CPIA)

World Development (1996) Special issue on social capital and economic development. Vol 24(6).

Zak, Paul and Stephen Knack (1999) 'Trust and growth' Mimeo, Department of Economics, Claremont Graduate University 


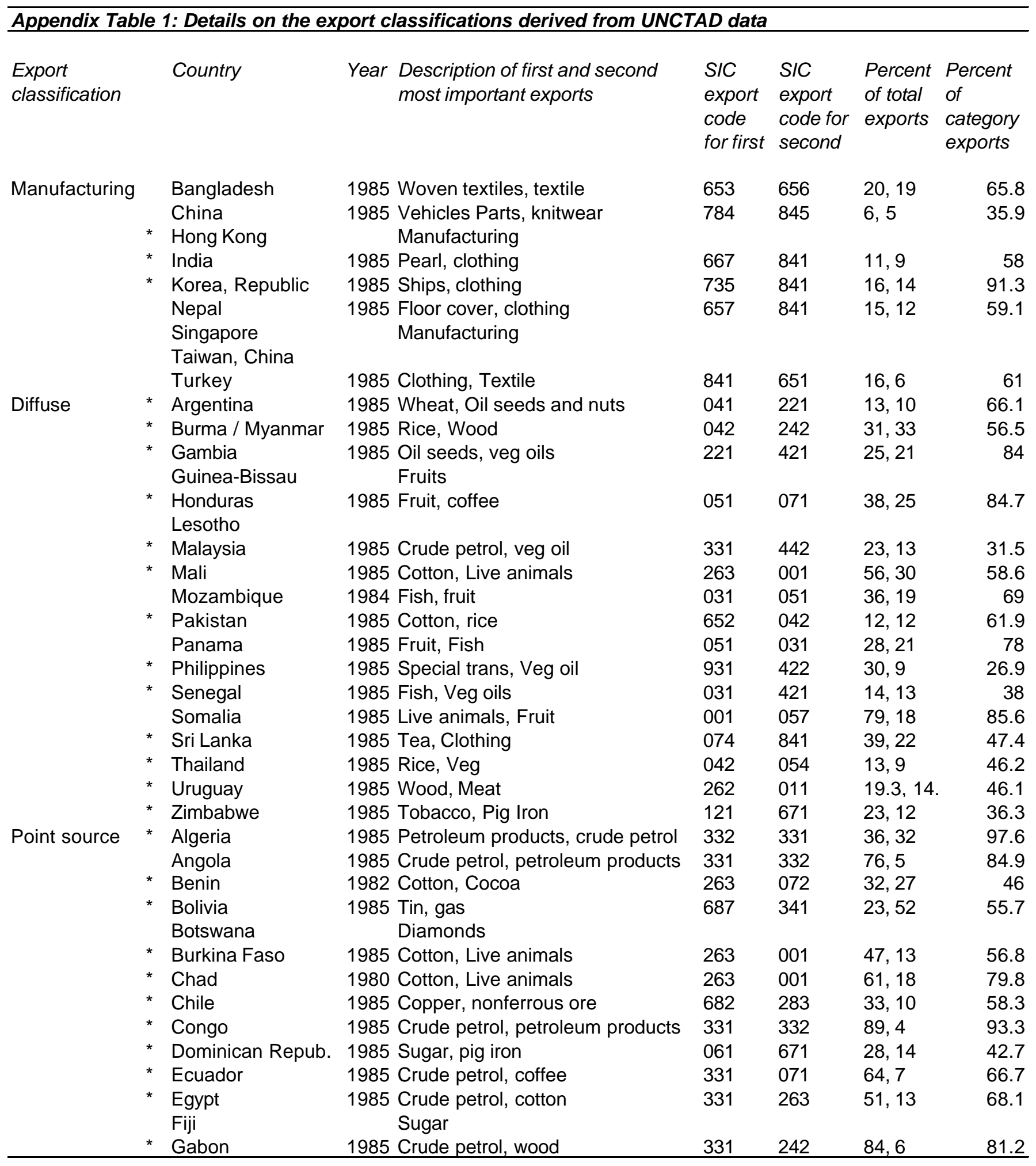




\begin{tabular}{|c|c|c|c|c|c|c|}
\hline \multicolumn{7}{|c|}{ Appendix Table 1 (continued) } \\
\hline \multirow{30}{*}{$\begin{array}{l}\text { Point source } \\
\text { (continued) }\end{array}$} & \multirow{2}{*}{\multicolumn{6}{|c|}{ Guinea }} \\
\hline & & & & & & \\
\hline & \multicolumn{6}{|l|}{ * Guyana } \\
\hline & * Indonesia & 1985 Crude petrol, gas & 331 & 341 & 48,18 & 68.6 \\
\hline & * Iran & 1987 Crude petrol, tapestry & 331 & 657 & 95,2 & 95.8 \\
\hline & Iraq & 1985 Crude petrol, fruit & 331 & 051 & 95,0 & 98.8 \\
\hline & * Jamaica & 1986 Inorganic elements, nonferrous m & 513 & 283 & 40,20 & 51.9 \\
\hline & * Jordan & 1985 Fertilizers (crude), Fertilizer (man & 271 & 561 & 35,14 & 43.3 \\
\hline & Liberia & 1985 Iron, rubber & 281 & 231 & 63,19 & 62.9 \\
\hline & * Malawi & 1983 Tobacco, tea & 121 & 074 & 48,24 & 96 \\
\hline & * Mauritania & 1985 Iron, fish & 281 & 031 & 44,40 & 58.3 \\
\hline & * Mauritius & 1985 Sugar, clothing & 061 & 841 & 47,29 & 49.8 \\
\hline & * Mexico & 1985 Crude petrol, petroleum products & 331 & 332 & 56,5 & 60 \\
\hline & $\begin{array}{l}\text { * Morocco } \\
\text { Namibia }\end{array}$ & 1985 Fertilizers, Inorganic elements & 271 & 513 & 23,16 & 40.5 \\
\hline & * Niger & 1981 Uranium, live animals & 286 & 001 & 81,14 & 80 \\
\hline & $\begin{array}{l}\text { Nigeria } \\
\text { Oman }\end{array}$ & 1985 Crude petrol, cocoa & 331 & 072 & 90,2 & 96.7 \\
\hline & Papua New Guinea & 1985 Nonferrous metal, Coffee & 283 & 071 & 35,14 & 45.1 \\
\hline & * Paraguay & 1985 Cotton, Oil & 263 & 221 & 43,33 & 49.5 \\
\hline & * Peru & 1985 Petrol, nonferrous metal & 332 & 283 & 16,14 & 40.8 \\
\hline & Saudi Arabia & & & & & \\
\hline & * Sierra Leone & 1985 Pearl, Nonferrous metal & 667 & 283 & 36,26 & 34.8 \\
\hline & * South Africa & 1985 Special, Coal & 931 & 321 & 54,6 & 34.2 \\
\hline & Sudan & 1985 Cotton, Oil Seeds & 263 & 221 & 48,15 & 71.3 \\
\hline & * Syria & 1985 Crude petrol, petroleum products & 331 & 332 & 49,19 & 74.1 \\
\hline & * Togo & 1985 Fertilizers, Cocoa & 271 & 072 & 49,16 & 53.6 \\
\hline & * Trinidad \& Tobago & & & & & \\
\hline & * Tunisia & 1985 Crude Petrol, Clothing & 331 & 841 & 40,17 & 44.5 \\
\hline & * Venezuela & 1985 Crude petrol, petroleum products & 331 & 332 & 46,29 & 80 \\
\hline & * Zaire & 1985 Copper, Crude petrol & 682 & 331 & 45,22 & 44.2 \\
\hline & * Zambia & 1985 Copper, zinc & 682 & 686 & 88,2 & 93.4 \\
\hline Coffee/cocoa & * Brazil & 1985 Coffee, petroleum products & 071 & 332 & 10,7 & 37 \\
\hline & * Burundi & 1985 Coffee, tea & 071 & 074 & 84,6 & 92.2 \\
\hline & * Cameroon & 1986 Coffee, cocoa & 071 & 072 & 28,22 & 52.5 \\
\hline & Central African Rep & 1985 Coffee, Wood & 071 & 242 & 35,24 & 41.6 \\
\hline & * Colombia & 1985 Coffee, petroleum products & 071 & 332 & 51,13 & 59.3 \\
\hline & * Costa Rica & 1985 Coffee, fruit & 071 & 051 & 30,24 & 60.5 \\
\hline & * Cote d'Ivoire & 1985 Cocoa, Coffee & 072 & 071 & 32,25 & 68 \\
\hline & * El Salvador & 1985 Coffee, Sugar & 071 & 061 & 63,4 & 51.3 \\
\hline & Ethiopia & 1985 Coffee, hides & 071 & 211 & 63,13 & 71.2 \\
\hline & * Ghana & 1985 Cocoa, Aluminum & 072 & 684 & 66,6 & 69.3 \\
\hline & * Guatemala & 1985 Coffee, Crude veg materials & 071 & 292 & 35,8 & 58.1 \\
\hline & * Haiti & 1985 Coffee, Clothing & 071 & 841 & 27,16 & 74.2 \\
\hline & * Kenya & 1985 Coffee, tea & 071 & 074 & 27,25 & 63.6 \\
\hline & * Madagascar & 1985 Coffee, spices & 071 & 075 & 39,29 & 79.2 \\
\hline & * Nicaragua & 1985 Coffee, Cotton & 071 & 263 & 38,33 & 58.2 \\
\hline & * Rwanda & 1985 Coffee, Tin & 071 & 687 & 43,9 & 76.4 \\
\hline & * Tanzania & 1985 Coffee, Cotton & 071 & 263 & 39,11 & 68.1 \\
\hline & * Uganda & 1985 Coffee, Hides & 071 & 211 & $71.3,6.9$ & 90 \\
\hline
\end{tabular}

Notes: Export classifications based on data from UNCTAD (1988)

Countries marked with * are included in the econometric models documented in Tables 3 and 4.

See the text for a description of the classification methodology 


\section{Appendix 2: Indices of net export}

The Statistics Canada World Trade Analyzer database provides data for 600 commodity groups for 192 countries for up to 19 years, 1980 through 1998. Statistics Canada is responsible for the compilation of the data which is organized according to Standard International Trade

Classification (SITC). Appendix table 2 describes the mapping from two digit SITC codes into our classifications.

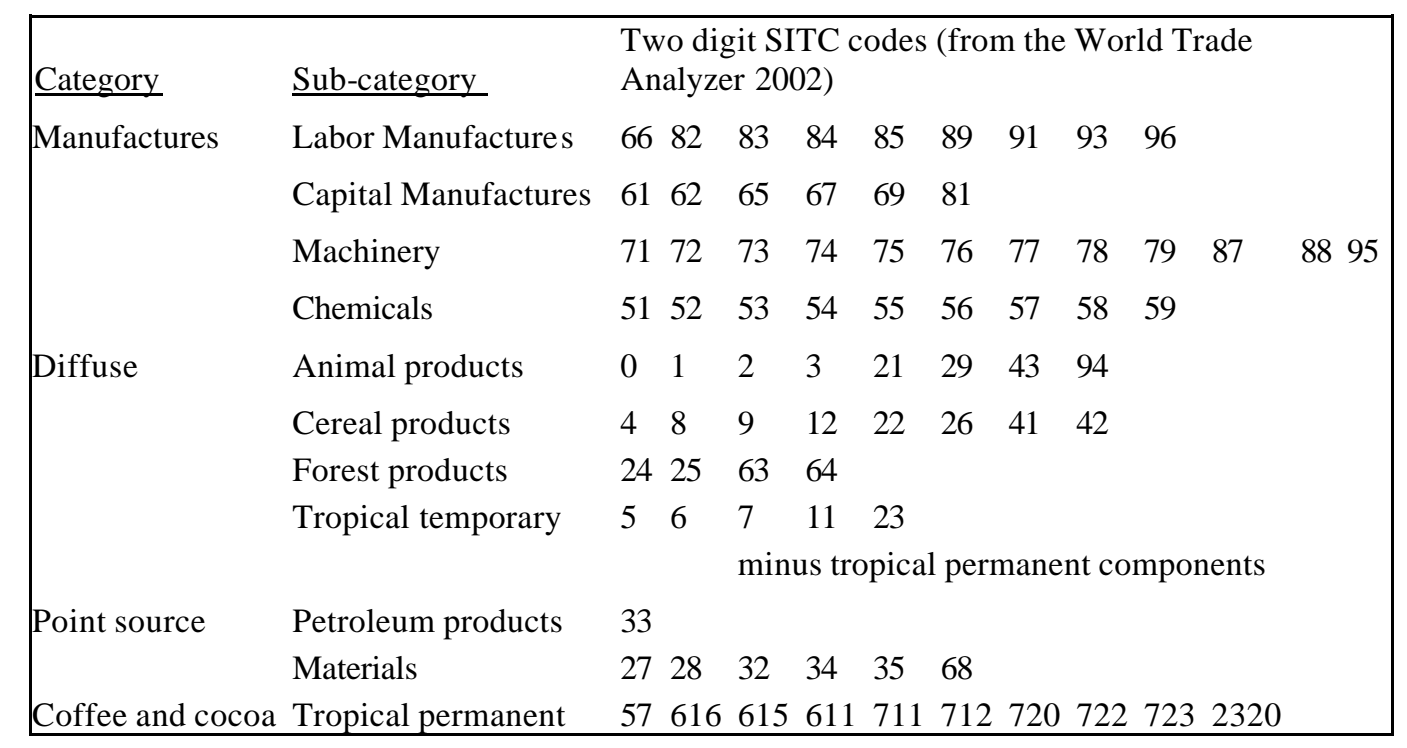

For additional detail on the rationale behind the grouping, see (Leamer 1984). We thank Peter Schott for providing this information. 
Variable name $\quad$ Year(s)

Dependent variable

Per capita growth rate

$1975-1997$

Natural resource variables

Manufactures index

Diffuse index

Point source index

Coffee and cocoa index

Possible determinants of institutions

Ethnic fractionalization

Predicted trade share

Latitude

English language

European language

Possible determinants of economic growth

GDP per capita

Secondary school achievement

Trade openness

Change in terms of trade

Share of primary exports/GDP

Sub-Saharan Africa

Europe and Middle East

Latin America

East Asia

Institutions

Rule of law

Political instability and violence

Government effectiveness

Control of corruption

Voice and accountability

Regulatory burden

Law and Order Tradition

Quality of the Bureaucracy

Political rights

Civil Liberties

Property rights and rule-based governance
Source

Entire sample Regression sample

$\mathrm{N}$ Mean STD $\mathrm{N}$ Mean STD

$1980 \quad$ Statistics Canada (2002) $\quad 88 \quad-0.3390 .267 \quad 66 \quad-0.333 \quad 0.248$

$1980 \quad$ Statistics Canada (2002) $\quad 88 \quad 0.0250 .178 \quad 66 \quad 0.044 \quad 0.185$

$1980 \quad$ Statistics Canada (2002) $\quad 88 \quad 0.1150 .275 \quad 66 \quad 0.116 \quad 0.266$

$\begin{array}{llllllll}1980 & \text { Statistics Canada (2002) } & 88 & 0.059 & 0.082 & 66 & 0.066 & 0.088\end{array}$

$\begin{array}{llllllll}1972 & \text { Easterly (2000) } & 84 & 48.6 & 29.5 & 66 & 48.2 & 30.7\end{array}$

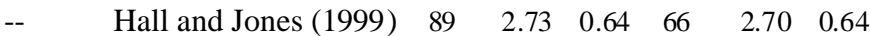

$\begin{array}{llllllll}-- & \text { Hall and Jones (1999) } & 89 & 6.20 & 18.09 & 66 & 6.22 & 18.18\end{array}$

$\begin{array}{llllllll}-- & \text { Hall and Jones (1999) } & 88 & 0.04 & 0.16 & 66 & 0.04 & 0.19\end{array}$

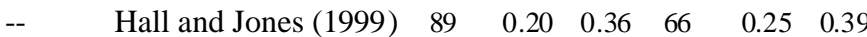

$1975 \quad$ World Bank (2002) $\quad 90 \quad 2.21 \quad 2.03 \quad 66 \quad 2.13 \quad 1.74$

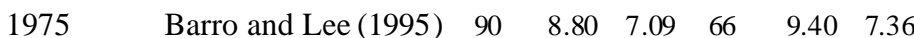

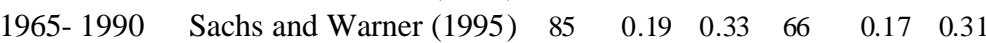

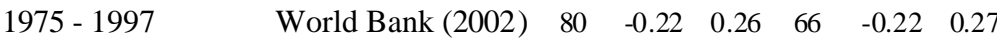

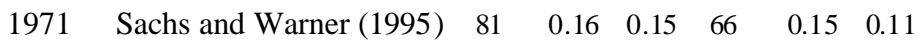

$\begin{array}{llllllll}-- & -- & 90 & 0.46 & 0.50 & 66 & 0.44 & 0.50\end{array}$

$\begin{array}{lllllllll}-- & -- & 90 & 0.12 & 0.33 & 66 & 0.11 & 0.31\end{array}$

$\begin{array}{llllllll}-- & -- & 90 & 0.24 & 0.43 & 66 & 0.32 & 0.47\end{array}$

$\begin{array}{llllllll}-- & -- & 90 & 0.11 & 0.32 & 66 & 0.08 & 0.27\end{array}$

2000/01 Kaufmann et al. (2002) $\quad 89 \quad-0.37 \quad 0.72 \quad 66 \quad-0.38 \quad 0.68$

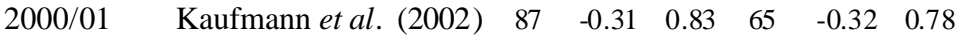

2000/01 Kaufmann et al. (2002) $\quad 86 \quad-0.33 \quad 0.78 \quad 64 \quad-0.33 \quad 0.69$

2000/01 Kaufmann et al. (2002) $\quad 86 \quad-0.34 \quad 0.68 \quad 64 \quad-0.38 \quad 0.62$

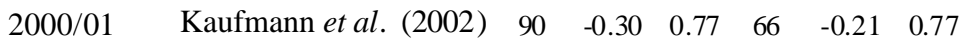

2000/01 Kaufmann et al. (2002) $\quad 89 \quad-0.11 \quad 0.78 \quad 66 \quad-0.06 \quad 0.71$

1984-1998 $\quad \begin{array}{lllllll}\text { Easterly (2000) } & 78 & 2.95 & 0.95 & 59 & 2.90 & 0.81\end{array}$

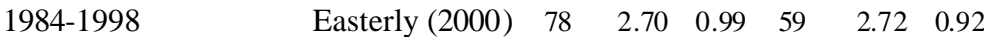

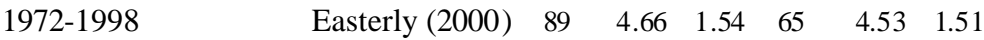

$\begin{array}{llllllll}1972-1998 & \text { Easterly (2000) } & 89 & 4.63 & 1.27 & 65 & 4.48 & 1.20\end{array}$

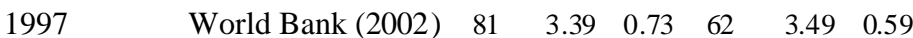

Note: last columns are sample sizes, means, and standard deviations for the entire sample and the regression sample. 


\begin{tabular}{|c|c|c|c|c|c|c|}
\hline \multicolumn{7}{|c|}{ Appendix Table 3: Determinants of economic growth: $1974-1997$} \\
\hline Specification & $(1)$ & $(2)$ & $(3)$ & $(4)$ & $(5)$ & $(6)$ \\
\hline Estimation procedure & OLS & 3SLS & 3SLS & 3SLS & 3SLS & 3SLS \\
\hline \multirow[t]{2}{*}{ Constant } & $4.15^{* *}$ & $4.71 * *$ & $4.19 * *$ & $4.21 * *$ & $4.42 * *$ & $4.12 * *$ \\
\hline & $(0.86)$ & $(1.26)$ & $(0.89)$ & $(0.86)$ & $(1.14)$ & $(0.85)$ \\
\hline \multirow[t]{2}{*}{ Rule of law } & 1.33 ** & 1.86 & 1.36 ** & 1.38 ** & 1.58 & 1.30 ** \\
\hline & $(0.33)$ & $(0.97)$ & $(0.50)$ & $(0.45)$ & $(0.84)$ & $(0.44)$ \\
\hline \multirow[t]{2}{*}{ GDP per capita } & -0.11 & -0.15 & -0.11 & -0.11 & -0.13 & -0.10 \\
\hline & $(0.13)$ & $(0.14)$ & $(0.12)$ & $(0.12)$ & $(0.13)$ & $(0.12)$ \\
\hline \multirow[t]{2}{*}{ Secondary school achievement } & -0.03 & -0.04 & -0.03 & -0.03 & -0.04 & -0.03 \\
\hline & $(0.03)$ & $(0.04)$ & $(0.03)$ & $(0.03)$ & $(0.04)$ & $(0.03)$ \\
\hline \multirow[t]{2}{*}{ Trade openness } & $2.15^{* *}$ & 1.79 & 2.12 ** & $2.11 * *$ & 1.97 * & 2.16 ** \\
\hline & $(0.73)$ & $(0.92)$ & $(0.72)$ & $(0.70)$ & $(0.85)$ & $(0.70)$ \\
\hline \multirow[t]{2}{*}{ Change in terms of trade } & $-1.62 * *$ & $-1.64 * *$ & $-1.62 * *$ & $-1.62 * *$ & -1.63 ** & $-1.62 * *$ \\
\hline & $(0.63)$ & $(0.59)$ & $(0.57)$ & $(0.57)$ & $(0.58)$ & $(0.57)$ \\
\hline \multirow[t]{2}{*}{ Share of primary exports/GDP } & -1.36 & -1.63 & -1.37 & -1.38 & -1.49 & -1.34 \\
\hline & $(1.68)$ & (1.64) & $(1.55)$ & $(1.54)$ & $(1.60)$ & $(1.54)$ \\
\hline \multirow[t]{2}{*}{ Sub-Saharan Africa } & $-3.43 * *$ & $-3.43 * *$ & $-3.43 * *$ & $-3.43 * *$ & $-3.43 * *$ & -3.43 ** \\
\hline & $(0.83)$ & $(0.77)$ & $(0.76)$ & $(0.76)$ & $(0.76)$ & $(0.76)$ \\
\hline \multirow[t]{2}{*}{ Europe and Middle East } & $-2.38 *$ & $-2.61 * *$ & $-2.39 * *$ & $-2.40 * *$ & $-2.49 * *$ & $-2.36 * *$ \\
\hline & $(0.94)$ & $(0.96)$ & $(0.87)$ & $(0.87)$ & $(0.93)$ & $(0.87)$ \\
\hline \multirow[t]{2}{*}{ Latin America } & -2.89 ** & -2.83 ** & $-2.88 * *$ & $-2.88^{* *}$ & -2.86 ** & -2.89 ** \\
\hline & $(0.83)$ & $(0.78)$ & $(0.76)$ & $(0.75)$ & $(0.76)$ & $(0.75)$ \\
\hline \multirow[t]{2}{*}{ East Asia } & -1.05 & -1.06 & -1.05 & -1.05 & -1.05 & -1.05 \\
\hline & $(1.04)$ & $(0.97)$ & $(0.95)$ & $(0.95)$ & $(0.95)$ & $(0.95)$ \\
\hline Adjusted r-squared & 0.47 & 0.54 & 0.56 & 0.56 & 0.55 & 0.56 \\
\hline Sample size & 65 & 65 & 65 & 65 & 65 & 65 \\
\hline \multicolumn{2}{|l|}{ Instruments } & Partial W's & NR & $\begin{array}{r}\text { Partial W's } \\
\text { and NR }\end{array}$ & Full W's & $\begin{array}{c}\text { Full W's } \\
\text { and NR }\end{array}$ \\
\hline Hausman test & -- & 0.95 & 0.57 & 0.89 & 0.96 & 0.92 \\
\hline Overidentification test & -- & 0.97 & 0.30 & 0.72 & 0.90 & 0.76 \\
\hline Hausman-Taylor test & -- & -- & -- & 0.64 & 0.51 & 0.66 \\
\hline
\end{tabular}

Notes:Dependent variable is the anuual growth rate in GDP: 1975 - 1997.

* significant at 5\% level; ** significant at $1 \%$ level. P - values listed for the three final statistical tests.

See the text for descriptions of the variables, the econometric specifications, and the statistical tests. 